\title{
CHLORIDE METABOLISM AND PLASMA AMINO ACID LEVELS IN PRIMARY ATYPICAL PNEUMONIA
}

\author{
By KENDALL EMERSON, JR.,1 EDWARD CHARLES CURNEN,1 GEORGE \\ SWOPE MIRICK,1 AND JAMES EDWIN ZIEGLER, JR. ${ }^{2}$ \\ (From the United States Navy Research Unit at the Hospital of The Rockefeller Institute \\ for Medical Research, New York City)
}

(Received for publication March 22, 1943)

In pneumococcus pneumonia, a tendency to store excessive amounts of ingested salt and water during the acute stage and to excrete this excess following the crisis has been described by numerous observers ( 1 to 4 ). Another characteristic metabolic disturbance in this disease, noted by Farr et al. (5), is a depression of the plasma amino acid level, as measured by the ninhydrin technique (6), during the acute phase, with a rise to normal at the time of the crisis. In order to discover whether or not such disturbances occur in primary atypical pneumonia $(7,8)$ (so-called virus pneumonia, acute pneumonitis, etc.), chloride balances and plasma amino acid levels have been followed in 10 adult male patients, showing the common signs and symptoms of this disease.

\section{METHODS}

The patients were placed on measured salt diets as soon as possible after admission to this hospital. In 3 cases, the temperatures fell to normal before balance studies could be started, so that data only during the convalescent period were obtained. The remaining 7 cases were observed for from 2 to 13 days of their acute illness and from 3 to 7 days after their temperatures had fallen to normal. Four of these (Nos. 1, 2, 3, and 7) were allowed a salt intake as desired; in the remaining 3 (Nos. 4,5 , and 6 ), the intake was kept high by the addition of 3 grams of $\mathrm{NaCl}$ daily to the diet.

Daily urine chlorides were determined by Sendroy's method (9). Blood samples were drawn under oil on each patient at the beginning and at the end of the period of observation. Plasma amino acids were determined by a modification (10) of the original ninhydrin method used by Farr (5). Serum chlorides were determined on each patient by the method of Van Slyke and Sendroy

\footnotetext{
1 Lieutenant, Medical Corps, United States Naval Reserve.

2 Lieutenant (j.g.), Medical Corps, United States Naval Reserve.

Note: The Bureau of Medicine and Surgery does not necessarily undertake to endorse views or opinions which are expressed in this paper.
}

(11), and serum $\mathrm{CO}_{2}$ content was estimated gasometrically (12).

\section{RESULTS}

The data are summarized in Table I, where average figures for daily temperature peaks, fluid intake, urine volume, and sodium chloride balances, during the acute and convalescent stages, are given, together with the serum chloride and $\mathrm{CO}_{2}$ concentrations, the plasma amino acid level, and the body weight, measured at the beginning and end of the period of observation of each patient.

The 3 patients (Nos. 1, 2, and 3) who received less than $60 \mathrm{mM}$. (3.5 grams) of $\mathrm{NaCl}$ in their diet in the acute stage all excreted more in their urine than they took in. This chloride loss is reflected in the low serum chloride levels which were found in all cases, except No. 7, in the initial stage of the disease. During convalescence, the salt intake of these 3 patients increased but their urinary chloride either stayed at the same level or decreased sharply, with the result that there was a marked increase in chloride retention in convalescence. Simultaneously, their serum chloride concentrations rose. The 3 patients (Nos. 8, 9, and 10) observed only during the convalescent period also showed relatively high retention of chloride and gave no indication of an epicritical chloride or water diuresis. In the 3 patients (Nos. 4, 5, and 6) consuming more than $90 \mathrm{mM}$. (5.2 grams) of $\mathrm{NaCl}$ per day, the urinary chloride excretion during the acute stage remained below the intake but was not excessively depressed. In the convalescent stage, as the serum chloride concentration rose and more salt was diverted from extra-renal channels of excretion, skin, lungs, etc., to the kidneys, the urinary chloride rose to normal levels.

All of these patients, except No. 4, lost weight during the course of their illness and in none can 
TABLE I

Average daily sodium chloride balance and the serum chloride, $\mathrm{CO}_{2}$, and plasma amino acid levels in primary atypical pneumonia

\begin{tabular}{|c|c|c|c|c|c|c|c|c|c|c|c|c|}
\hline \multirow{2}{*}{$\begin{array}{l}\text { Patient } \\
\text { number }\end{array}$} & \multirow{2}{*}{$\begin{array}{l}\text { Stage } \\
\text { of } \\
\text { disease }\end{array}$} & \multirow{2}{*}{$\begin{array}{l}\text { Number } \\
\text { of days } \\
\text { aver-- } \\
\text { aged }\end{array}$} & \multirow{2}{*}{$\begin{array}{c}\text { Daily } \\
\text { average } \\
\text { temper- } \\
\text { ature } \\
\text { peak }\end{array}$} & \multirow{2}{*}{ Weight } & \multirow{2}{*}{$\begin{array}{c}\text { Fluid } \\
\text { intake }\end{array}$} & \multirow{2}{*}{$\begin{array}{c}\text { Urine } \\
\text { volume }\end{array}$} & \multirow{2}{*}{$\begin{array}{l}\text { Chloride } \\
\text { intake }\end{array}$} & \multirow{2}{*}{$\begin{array}{c}\text { Urine } \\
\text { chloride }\end{array}$} & \multirow{2}{*}{$\begin{array}{c}\text { Intake } \\
\text { minus } \\
\text { urinary } \\
\text { output }\end{array}$} & \multicolumn{2}{|c|}{ Serum } & \multirow{2}{*}{$\begin{array}{c}\text { Plasma } \\
\text { amino } \\
\text { acid } \\
\text { nitrogen }\end{array}$} \\
\hline & & & & & & & & & & Chloride & $\mathrm{CO}_{2}$ & \\
\hline & & & ${ }^{\circ} F$. & kgm. & $c c . p$ & $d a y$ & $m M$ & er day & & $m M$. & $L$. & $\begin{array}{l}\text { mgm. per } \\
100\end{array}$ \\
\hline 1 & $\begin{array}{l}\text { acute } \\
\text { conv. }\end{array}$ & $\begin{array}{l}3 \\
3\end{array}$ & $\begin{array}{r}103.1 \\
99.1\end{array}$ & $\begin{array}{l}58.5 \\
56.7\end{array}$ & $\begin{array}{l}2253 \\
2196\end{array}$ & $\begin{array}{l}2280 \\
2196\end{array}$ & $\begin{array}{l}21.2 \\
67.3\end{array}$ & $\begin{array}{l}26.6 \\
21.5\end{array}$ & $\begin{array}{r}5.4 \\
+45.8\end{array}$ & $\begin{array}{r}98.8 \\
100.0\end{array}$ & $\begin{array}{l}28.6 \\
32.7\end{array}$ & 4.15 \\
\hline 2 & $\begin{array}{l}\text { acute } \\
\text { conv. }\end{array}$ & $\begin{array}{l}3 \\
7\end{array}$ & $\begin{array}{r}104.0 \\
99.5\end{array}$ & $\begin{array}{l}62.3 \\
54.5\end{array}$ & $\begin{array}{l}2526 \\
2160\end{array}$ & $\begin{array}{l}1458 \\
1140\end{array}$ & $\begin{array}{l}51.1 \\
88.2\end{array}$ & $\begin{array}{r}54.5 \\
4.5\end{array}$ & $\begin{array}{r}3.4 \\
+83.7\end{array}$ & $\begin{array}{l}91.4 \\
93.0\end{array}$ & 33.0 & 3.92 \\
\hline 3 & $\begin{array}{l}\text { acute } \\
\text { conv. }\end{array}$ & $\begin{array}{r}13 \\
4\end{array}$ & $\begin{array}{r}101.9 \\
99.4\end{array}$ & $\begin{array}{l}74.4 \\
66.9\end{array}$ & $\begin{array}{l}2809 \\
2312\end{array}$ & $\begin{array}{l}1596 \\
1355\end{array}$ & $\begin{array}{l}55.4 \\
74.8\end{array}$ & $\begin{array}{l}55.9 \\
58.3\end{array}$ & $\begin{array}{r}0.5 \\
+16.5\end{array}$ & $\begin{array}{r}97.3 \\
103.9\end{array}$ & 26.5 & $\begin{array}{l}3.68 \\
3.49\end{array}$ \\
\hline 4 & $\begin{array}{l}\text { acute } \\
\text { conv. }\end{array}$ & $\begin{array}{l}2 \\
4\end{array}$ & $\begin{array}{r}101.3 \\
99.2\end{array}$ & $\begin{array}{l}77.6 \\
78.2\end{array}$ & 3598 & $\begin{array}{l}2165 \\
1995\end{array}$ & $\begin{array}{r}93.0 \\
130.5\end{array}$ & $\begin{array}{r}73.0 \\
122.4\end{array}$ & $\begin{array}{l}+20.1 \\
+8.1\end{array}$ & $\begin{array}{r}97.7 \\
100.0\end{array}$ & $\begin{array}{l}30.5 \\
30.0\end{array}$ & 3.80 \\
\hline 5 & $\begin{array}{l}\text { acute } \\
\text { conv. }\end{array}$ & $\begin{array}{l}4 \\
4\end{array}$ & $\begin{array}{r}103.3 \\
99.1\end{array}$ & $\begin{array}{l}61.0 \\
54.2\end{array}$ & $\begin{array}{l}2813 \\
2285\end{array}$ & $\begin{array}{l}1720 \\
1436\end{array}$ & $\begin{array}{l}101.2 \\
120.8\end{array}$ & $\begin{array}{l}54.9 \\
96.5\end{array}$ & $\begin{array}{r}+46.3 \\
+24.3\end{array}$ & $\begin{array}{l}91.2 \\
95.2\end{array}$ & $\begin{array}{l}28.9 \\
28.6\end{array}$ & $\begin{array}{l}3.28 \\
3.92\end{array}$ \\
\hline 6 & $\begin{array}{l}\text { acute } \\
\text { conv. }\end{array}$ & $\begin{array}{l}8 \\
5\end{array}$ & $\begin{array}{r}102.2 \\
99.9\end{array}$ & $\begin{array}{l}85.7 \\
82.3\end{array}$ & $\begin{array}{l}3696 \\
2690\end{array}$ & $\begin{array}{l}2363 \\
1849\end{array}$ & $\begin{array}{l}107.4 \\
140.1\end{array}$ & $\begin{array}{r}78.8 \\
135.3\end{array}$ & $\begin{array}{r}+28.6 \\
+\quad 4.9\end{array}$ & $\begin{array}{l}95.6 \\
99.0\end{array}$ & 30.1 & $\begin{array}{l}3.93 \\
3.44\end{array}$ \\
\hline 7 & $\begin{array}{l}\text { acute } \\
\text { conv. }\end{array}$ & $\begin{array}{l}8 \\
7\end{array}$ & $\begin{array}{r}102.0 \\
99.8\end{array}$ & $\begin{array}{l}67.0 \\
61.2\end{array}$ & $\begin{array}{l}2690 \\
2773\end{array}$ & $\begin{array}{l}1038 \\
2093\end{array}$ & $\begin{array}{r}63.1 \\
121.1\end{array}$ & $\begin{array}{r}50.3 \\
116.5\end{array}$ & $\begin{array}{r}+12.8 \\
+4.6\end{array}$ & $\begin{array}{r}109.3 \\
99.0\end{array}$ & 28.4 & $\begin{array}{l}3.08 \\
4.07\end{array}$ \\
\hline 8 & $\begin{array}{l}\text { acute } \\
\text { conv. }\end{array}$ & $\begin{array}{l}1 \\
3\end{array}$ & $\begin{array}{r}104.6 \\
99.4\end{array}$ & $\begin{array}{l}70.6 \\
68.8\end{array}$ & 2380 & 2025 & 99.5 & 85.9 & +13.6 & $\begin{array}{l}93.3 \\
96.2\end{array}$ & $\begin{array}{l}31.0 \\
31.7\end{array}$ & $\begin{array}{l}3.88 \\
3.91\end{array}$ \\
\hline 9 & $\begin{array}{l}\text { acute } \\
\text { conv. }\end{array}$ & $\begin{array}{l}1 \\
2\end{array}$ & $\begin{array}{r}101.7 \\
99.6\end{array}$ & $\begin{array}{l}68.7 \\
67.7\end{array}$ & 2464 & 1705 & 106.6 & 49.6 & +57.0 & 99.2 & 29.9 & 4.27 \\
\hline 10 & $\begin{array}{l}\text { acute } \\
\text { conv. }\end{array}$ & $\begin{array}{l}1 \\
2\end{array}$ & $\begin{array}{r}102.2 \\
99.9\end{array}$ & $\begin{array}{l}72.7 \\
70.8\end{array}$ & 2548 & 1509 & 106.6 & 58.0 & +48.6 & 99.5 & 29.8 & 4.30 \\
\hline
\end{tabular}

it be said that there was a significant storage of salt and water during their acute illness or a salt and water diuresis in convalescence, resembling that described in pneumococcus pneumonia.

Case No. 7 was the only one exhibiting any of the phenomena seen in pneumococcus pneumonia. Of his relatively low daily chloride intake of 63 $\mathrm{mM}$. during his acute illness, the proportion excreted in the urine was less than on the much higher intake of $121 \mathrm{mM}$. in convalescence, and at the same time, his water output rose significantly in convalescence. He may be said, therefore, to have shown retention in the acute phase and a relative diuresis in convalescence. Unlike pneumococcus pneumonia, however, he had a high serum chloride level on admission which fell to normal during convalescence. It seems possible that his initial water retention was an attempt to restore a normal serum chloride level, resulting in an increase in total plasma volume which was subsequently reduced by the diuresis during convalescence. Like all the other patients (except No. 4), he showed a net weight loss during the whole period of observation.

Data at hand indicate that the lower limit of the normal plasma amino acid nitrogen level, by the method used in these studies, is approximately 3.5 $\mathrm{mgm}$. per $100 \mathrm{cc}$. None of the patients, therefore, with the exception again of No. 7 and possibly also of No. 5, showed a depression of the plasma amino acid level below normal. Three patients (Nos. 5, 7, and 8) showed a rise in their plasma amino acid level during convalescence, but patients Nos. 3 and 6 showed a drop. In this respect, again, primary atypical pneumonia does not resemble pneumococcus pneumonia.

\section{CONCLUSION}

In primary atypical pneumonia, unlike pneumococcus pneumonia, hypoaminoacidemia does not occur and there is no significant tendency to 
retain salt and water in the acute stage or to excrete an excess in convalescence.

The authors wish to express their appreciation to Dr. D. D. Van Slyke in whose laboratory this work was performed.

\section{BIBLIOGRAPHY}

1. Peabody, F. W., Studies of the inorganic metabolism in pneumonia with especial reference to calcium and magnesium. J. Exper. Med., 1913, 17, 71.

2. Haden, R. L., The clinical significance of the chlorid metabolism in lobar pneumonia. Am. J. M. Sc., 1927, 174, 744.

3. Sunderman, F. W., Studies of serum electrolytes. IV. The chloride and nitrogen balances, and weight changes in pneumonia. J. Clin. Invest., 1929, 7, 313.

4. Wilder, T. S., and Drake, T. G. H., Metabolism of chloride and total fixed base in pneumonia and the relation to salt and water retention. J. Clin. Invest., $1929,7,353$.
5. Farr, L. E., et al., Hypoaminoacidemia in patients with pneumococcal pneumonia. Proc. Soc. Exper. Biol. and Med., 1940, 44, 290.

6. Van Slyke, D. D., Dillon, R. T., MacFadyen, D. A., and Hamilton, P., Gasometric determination of carboxyl groups in free amino acids. J. Biol. Chem., 1941, 141, 627.

7. Primary atypical pneumonia, etiology unknown. Army Medical Bulletin, 1942, No. 61, p. 31.

8. Dingle, J. H., and Finland, M., Medical progress; virus pneumonias; primary atypical pneumonias of unknown etiology. New England J. Med., 1942, 227, 378.

9. Sendroy, J., Jr., Microdetermination of chloride in biological fluids, with solid silver iodate. II. Titrimetric analysis. J. Biol. Chem., 1937, 120, 405.

10. Van Slyke, D. D., and Hamilton, P., To be published.

11. Peters, J. P., and Van Slyke, D. D., Quantitative Clinical Chemistry. Vol. II. Methods. Williams and Wilkins, Baltimore, 1932, pps. 835 and 837.

12. Ibid., p. 283. 